\title{
Biocidal and resistance-inducing effects of chitosan on phytopathogens
}

\author{
Rashit Tarakanov ${ }^{1, *}$, Balzhima Shagdarova ${ }^{2}$, Valery Varlamov ${ }^{2}$, and Fevzi Dzhalilov ${ }^{1}$ \\ ${ }^{1}$ Russian State Agrarian University - Moscow Timiryazev Agricultural Academy, 127550 Moscow, \\ Russian Federation \\ ${ }^{2}$ Research Center of Biotechnology of the Russian Academy of Sciences, 119071 Moscow, Russian \\ Federation
}

\begin{abstract}
In connection with the of the law adoption on organic products in the Russian Federation, as well as the appearance of fungicide-resistant forms of phytopathogens, the search for new preparations of biological origin for plant protection from disease remains relevant. Chitosan is a promising substance obtained from shells of crustaceans, zygomycete fungi: on the one hand, it prevents the pathogen's penetration into the plant inducing a horizontal resistance, and on the other, it has a bactericidal effect against some bacteria and fungi. This article shows the biocidal effect of chitosan hydrolysate with a molecular weight of the main fraction of 33.7 $\mathrm{kDa}$ in relation to 5 phytopathogenic bacteria. The minimum bactericidal concentration ranged from 0.25 to $0.5 \%$. It was noted that the substance acts more actively against Gram-negative bacteria than in relation to Grampositive. Biological substance efficacy on artificial infectious background of cucumber downy mildew during preventive treatment amounted to the average of $55.4 \%$ compared to control with no treatment.
\end{abstract}

\section{Introduction}

The search for alternatives to chemical pesticides is a topical area of research in agricultural biology $[1,2]$. The acute task is, on the one hand, in reducing the pesticide load on agrocenoses of intensive type, and on the other - the development of technologies for biologized plant protection against phytopathogens in organic crop production. Another problem is increased resistance of phytopathogenic bacteria and fungi to existing classes of bactericides and fungicides, which entails increased application doses and accumulation of residual quantities of pesticides in crop production $[3,4]$.

Substances inducing non-specific plant resistance of plants to adverse factors, inc. i.e. to pathogens of diseases can help in solving these problems. These substances include some terpenoids, polyphenols, alkaloids, polysaccharides and organic acids [5, 6]. Plants treated with these compounds become locally resistant to infection penetration by binding cell membrane receptors to elicitor molecules [7].

One of the most promising of them is chitosan - a biodegradable polysaccharide obtained from external skeletons of crustaceans, arthropods mantles and zygomycetes fungi [8]. The

\footnotetext{
*Corresponding author: tarakanov.rashit@mail.ru
} 
action mechanism of the substance is based on the recognition of the surface molecules of phytopathogens, which serves as a primary signal that drives a complex processes network of induction and regulation of phytoimmunity [9]. Earlier studies show that the inducing chitosan effect manifests itself in increased peroxidase (POD) and polyphenol oxidase (PPO) activity, which in turn triggers the cascade of biochemical reactions resulting in the synthesis of phytoalexins [9].

In addition to inducing action, the substance also has biocidal action against certain bacteria and fungi $[9,10]$. Therefore, the possibility of its use in integrated plant protection against phytopathogens as a substance with a bidirectional action mechanism (biocidal and inducing resistance) is an extremely crucial task.

The aim of the study was to investigate the action of chitosan hydrolysate against certain phytopathogenic bacteria and to assess the biological effectiveness of the substance against cucumber downy mildew in preventive treatment.

\section{Materials and Methods}

\subsection{Synthesis of chitosan}

Chitosan hydrolyzate has been produced by chemical depolymerization of high-molecular chitosan with nitric acid. Characteristics of chitosan hydrolysate: $\mathrm{pH} 5.5$; concentration - 10 $\mathrm{mg} / \mathrm{ml}$; deacetylation degree of the main fraction - $91 \%$, molecular weight of the main fraction - $33.7 \mathrm{kDa}$.

\subsection{Determination of antibacterial activity}

The following bacteries-pathogens of diseases were chosen as test objects: soybean (Pseudomonas syringae pv. glycinea CFBP 2214), beans (Xanthomonas axonopodis $p v$. phaseoli CFBP 2534), white cabbage (Xanthomonas campestris pv. campestris NCPPB 528T), pepper (Xanthomonas campestris. pv. vesicatoria ATCC 35937) and tomato (Clavibacter michiganensis pv. nebraskensis CFBP 2405). Bacteria cultures were stored in $15 \%$ glycerin at $-70{ }^{\circ} \mathrm{C}$.

Suspension of 2 daily cultures' bacterial cells was prepared in sterile water with initial dilution to an optical density of 0.5 measured by a photometer at $590-610 \mathrm{~nm}$ and subsequent bringing to $10^{8} \mathrm{CFU}$ in $1 \mathrm{ml}$ concentration.

To determine the antibacterial activity of chitosan, a modified reductase test with resazurin described in the work [11] was used. The principle of the method is that in the presence of bacteria division in the medium, resazurin is oxidized to a fluorescent resorufin, which in turn changes the color of the nutrient medium or solution from blue to pinkishmauve, and then to pink. Operations were carried out in sterile 96-well round-bottom plate for cell culture (Corning, USA).

The experiment scheme included several chitosan concentrations $(0.005-0.7 \% \mathrm{v} / \mathrm{v})$ in a mixture with suspensions of tested bacteria, resazurin and nutrient medium (Table 1). There were three controls: no chitosan, no resazurin, and no bacteria suspension. The total volume of each slot for analysis was $200 \mu 1$. The experiment was repeated three times. 
Table 1. Ratio of chitosan, nutrient medium and resazurin volumes in plates for analysis.

\begin{tabular}{|c|c|c|c|c|c|c|}
\hline $\begin{array}{c}\text { Rows } \\
\text { of } \\
\text { slots }\end{array}$ & $\begin{array}{c}\text { Chitosan } \\
\text { concentration, \% }\end{array}$ & $\begin{array}{c}\text { The } \\
\text { content of } \\
\text { dry } \\
\text { chitosan } \\
\text { in } \\
\text { solution, } \\
\text { mg }\end{array}$ & $\begin{array}{c}\text { The content } \\
\text { of 1\% } \\
\text { chitosan in } \\
\text { a solution, } \\
\boldsymbol{\mu l}\end{array}$ & $\begin{array}{c}\mathbf{0 , 1 \%} \\
\text { resazurin } \\
\text { content in } \\
\text { solution, } \boldsymbol{\mu l}\end{array}$ & $\begin{array}{c}\text { Volume } \\
\text { of } \\
\text { bacterial } \\
\text { suspensi } \\
\text { on, } \boldsymbol{\mu l}\end{array}$ & $\begin{array}{c}\text { Volume } \\
\text { of liquid } \\
\text { nutrient } \\
\text { medium, } \\
\boldsymbol{\mu l}\end{array}$ \\
\hline $\mathbf{1}$ & Control (no chitosan) & - & - & 10 & 20 & 170 \\
\hline $\mathbf{2}$ & Control (no resazurin) & 1.4 & 140 & - & 20 & 40 \\
\hline $\mathbf{3}$ & Control (no bacteria) & 1.4 & 140 & 10 & - & 50 \\
\hline $\mathbf{4}$ & 0.7 & 1.4 & 140 & 10 & 20 & 30 \\
\hline $\mathbf{5}$ & 0.5 & 1 & 100 & 10 & 20 & 70 \\
\hline $\mathbf{6}$ & 0.3 & 0.6 & 60 & 10 & 20 & 110 \\
\hline $\mathbf{7}$ & 0.25 & 0.5 & 50 & 10 & 20 & 120 \\
\hline $\mathbf{8}$ & 0.1 & 0.2 & 20 & 10 & 20 & 150 \\
\hline $\mathbf{9}$ & 0.05 & 0.1 & 10 & 10 & 20 & 160 \\
\hline $\mathbf{1 0}$ & 0.025 & 0.05 & 5 & 10 & 20 & 165 \\
\hline $\mathbf{1 1}$ & 0.01 & 0.02 & 2 & 10 & 20 & 168 \\
\hline $\mathbf{1 2}$ & 0.005 & 0.01 & 1 & 10 & 20 & 169 \\
\hline
\end{tabular}

The plate was incubated at $28^{\circ} \mathrm{C}$ for 24 hours, after which the changes in coloring in the slots were recorded. In the well where bacteria multiplied, the blue resazurin color passed to a pinkish-mauve coloration

The YD medium was used as a liquid nutrient medium $(10.0 \mathrm{~g} / 1$ - yeast extract; $20.0 \mathrm{~g} / 1$ - sucrose).

The minimum inhibitory concentration (MIC) of chitosan against test objects was determined after considering the change in the solution color in slots with different chitosan concentrations.

The minimum chitosan concentration was taken as the minimum bactericidal concentration (MBC), in the presence of which through 48 hours of incubation, the number of living cells decreased by $99.9 \%$ compared to the initial quantity. The test of the living cells' presence was carried out by seeding $100 \mu \mathrm{l}$ of solution on a solid nutrient medium YD.

\subsection{Determination of inducing action on vegetative plants}

Checking the effect of chitosan hydrolysate on downy mildew was carried out on plants of Marfinsky cucumber variety susceptible to pathogen in the phase of three real cucumber leaves [12]. For this, the seeds were sown in plastic pots of 0.5 liters with turfy substrate and perlite (LLC "Veltorf", Russia) and cultivated in a greenhouse at an average temperature of $25 / 20^{\circ} \mathrm{C}$ (day/night) and natural light.

During vegetation, two treatments with chitosan hydrolysate were carried out. The first was preventive - 2 days before inoculation by the pathogen, the second - 6 days after the first treatment in order to aintain long-term induced immune status [13].

The treatment was carried out at a rate of $10 \%$ of the working solution of $10 \mathrm{ml}$ per 5 plants using a manual sprayer.

Conidial suspensions were prepared by washing the fragmentation spores off the affected leaves with deionized water. The conidial suspension's density was calculated using the Muse hematimeter (Luminex Corp.) and brought to a concentration of 104 
fragmentation spores per $\mathrm{ml}$ by dilution with deionized water. The experiment's repetition was three-fold with 5 plants per repetition.

A day before infection, humidity level close to $100 \%$ was ensured in the chamber with plants. After 24 hours, spraying with spore suspension was performed. After spraying, the initial air humidity (95\%) was maintained in the chamber and left for 48 hours at 20 degrees for spores' germination and pathogenesis start. Accounting results were carried out on 7,15 and 21 days after infection. Assessment of the disease development was carried out using a unified scale [12]. Statistical processing of the analyzed data was carried out by dispersion analysis using the programs Statistica 12.0 (StatSoft Co, USA) and Microsoft Excel 2013 (Microsoft Co., USA) with contrast of means on the Duncan criterion. Data expressed as a percentage was converted to arcsinus before processing.

\section{Results and discussion}

\subsection{Antibacterial action}

The analysis showed that the minimum inhibitory concentration of tested chitosan hydrolysate varied from 0.01 to $0.1 \%$, the minimum bactericidal concentration - from 0.25 to $0.5 \%$ (Fig. 1, Table 2). As it follows from the obtained data, MIC amounted to $0.1 \%$ for tested Gram-negative bacteria (Fig. 2). In relation to the pathogen of bacterial tomato cancer, this figure was lower at $0.01 \%$.

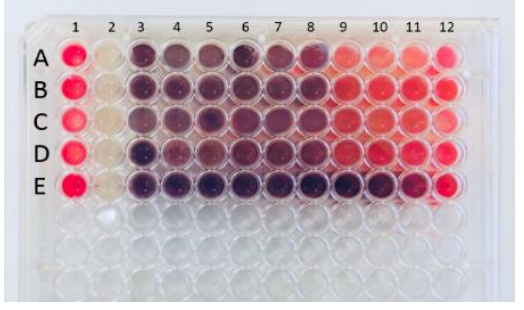

The data obtained are consistent with the literary information that the effective chitosan binding to the membrane structures of bacteria is determined by the structure peculiarities of their cell walls, that is, there are species differences in microorganisms' sensitivity to the chitosan polymer [13].

Fig. 1. Determination of the minimum inhibitory concentration in the test with resazurin. A - E - test objects (A - Pseudomonas syringae pv. glycinea, B - Xanthomonas axonopodis pv. phaseoli, C Xanthomonas campestris pv. campestris, D - Xanthomonas campestris. pv. vesicatoria, E - Clavibacter michighanensis pv. michighanensis).

Table 2. Results of MIC and MBC determination of chitosan hydrolyzate in relation to certain phytopathogenic bacteria.

\begin{tabular}{|c|c|c|}
\hline Organism & MIC, $\%$ & MBC, $\%$ \\
\hline Pseudomonas syringae pv. glycinea & 0.10 & 0.30 \\
\hline Xanthomonas axonopodis pv. phaseoli & 0.10 & 0.30 \\
\hline Xanthomonas campestris pv. campestris & 0.10 & 0.30 \\
\hline Xanthomonas campestris pv. vesicatoria & 0.10 & 0.25 \\
\hline $\begin{array}{c}\text { Clavibacter michiganensis subsp. } \\
\text { michiganensis }\end{array}$ & 0.01 & 0.50 \\
\hline
\end{tabular}

Interestingly, in the case of a minimum bactericidal concentration, the opposite trend was observed (Table 2). So, if MBC amounted to $0.25-0.30 \%$ in relation to Gram-negative bacteria, then relative to the Gram-positive bacterium Clavibacter michiganensis subsp. 
michiganensis this indicator was higher - $0.5 \%$. Most likely, this phenomenon is since the latter have a thicker peptidoglycan layer in comparison with Gram-negative bacteria.

\subsection{Inducing effect against cucumber false mildew.}

On the control version, epiphytotic development of cucumber downy mildew was noted. This phenomenon was facilitated by both susceptibility of the variety and the combination of high infectious pressure with optimal pathogenesis conditions (Fig. 2. Table $3)$.

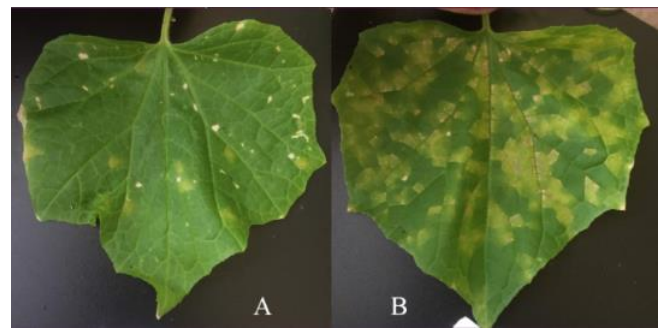

Fig. 2. Development of false mildew on Marfinsky cucumber variety leaves (A - when treated with chitosan hydrolyzate, B - control (water treatment) at 15 days after the first treatment with chitosan, 2020

On the option with chitosan hydrolysate treatment, although there was a high prevalence ( $72.7 \%$ on the 7 th day after infection), but the disease development on this option was weak, which is explained by the ability of chitosan to increase nonspecific plant resistance to phytopathogens. Phytotoxic effect against cucumber plants during treatment with chitosan hydrolysate was not revealed.

Table 3. Parameters of development and prevalence of false mildew on Marfinsky variety cucumber during treatment with chitosan hydrolysate, 2020

\begin{tabular}{|c|c|c|c|c|c|c|c|c|c|}
\hline \multirow[b]{3}{*}{ Treatment } & \multicolumn{9}{|c|}{ The period after the second treatment with chitosan, days } \\
\hline & \multicolumn{3}{|c|}{7} & \multicolumn{3}{|c|}{15} & \multicolumn{3}{|c|}{21} \\
\hline & $\begin{array}{c}\text { Disease } \\
\text { incidence, } \\
\%\end{array}$ & $\begin{array}{c}\text { Disease } \\
\text { severity, } \\
\%\end{array}$ & $\begin{array}{c}\text { Biological } \\
\text { efficiency, } \\
\%\end{array}$ & $\begin{array}{c}\text { Disease } \\
\text { incidence, } \\
\%\end{array}$ & $\left\{\begin{array}{c}\text { Disease } \\
\text { severity, } \\
\%\end{array}\right.$ & $\left\{\begin{array}{c}\text { Biological } \\
\text { efficiency, } \\
\%\end{array}\right.$ & $\begin{array}{c}\text { Disease } \\
\text { incidence, } \\
\%\end{array}$ & $\begin{array}{c}\text { Disease } \\
\text { severity, } \\
\%\end{array}$ & $\begin{array}{c}\text { Biological } \\
\text { efficiency, } \\
\%\end{array}$ \\
\hline $\begin{array}{c}\text { Control } \\
\text { (water } \\
\text { treatment) }\end{array}$ & $100 \mathrm{a}$ & $61.9 \mathrm{a}$ & - & $100 \mathrm{a}$ & $79.7 \mathrm{a}$ & - & $100 \mathrm{a}$ & $92.8 \mathrm{a}$ & - \\
\hline $\begin{array}{c}\text { Chitosan } \\
\text { hydrolyzate } \\
(0.1 \% \mathrm{w} / \mathrm{v})\end{array}$ & $72.7 \mathrm{~b}$ & $19.4 \mathrm{~b}$ & 68.6 & $75.0 \mathrm{~b}$ & $31.5 \mathrm{~b}$ & 60.4 & $89.6 \mathrm{~b}$ & $58.2 \mathrm{~b}$ & 37.3 \\
\hline
\end{tabular}

Note: There are no statistically reliable differences by the Duncan criterion at a $95 \%$ probability level in the table between the options marked with the same letters.

The incidence and severity of downy mildew development on cucumber in the option with chitosan treatment had statistically significant difference from the untreated control. The biological efficacy of chitosan hydrolyzate for cucumber downy mildew averaged over three records to $55.4 \%$.

At the same time, there was a drop in biological efficiency and an increase in development and prevalence after the second treatment. This fact can be explained by that the plants' immune response to phytopathogens after treatment with phytoalexin-inducing 
preparations has a tendency to fade, therefore the protective effect reduction due to lack of further processing started after the second treatment with the studied substance [14]. Apparently, an increase in the treatments' multiplicity will be able to solve this problem and the substance will consistently show its protective properties in dynamics.

\section{Conclusion}

As a result of the work, the minimum inhibitory and minimum bactericidal concentrations of chitosan hydrolyzate with molecular weight of the main fraction of 33.7 $\mathrm{kDa}$ were determined in respect of the most important pathogens of bacterial diseases of agricultural plants. The minimum bactericidal concentration ranged from 0.25 to $0.5 \%$. It was noted that the substance acts more actively against Gram-negative bacteria than in relation to Gram-positive, which is due to the fact that the latter have a thicker peptidoglycan layer, which interferes with chitosan hydrolysate biocidal effect in low concentration.

Test of chitosan hydrolysate in the concentration of $0.1 \%$ active substance during preventive treatment on artificial infectious background of cucumber downy mildew showed that biological efficacy averaged to $55.4 \%$ compared to the control sprayed with water. It was shown that the substance's resistance-inducing effect against the disease manifests itself only within 6-7 days, after which the effectiveness of the substance decreases.

The use of chitosan hydrolyzate in the fight against plant diseases can take its place in the technologies of growing organic products, as well as in intensive farms. After the selection of preparation forms, it is possible to create a line of chitosan-containing mixture preparations that have biocidal action and induces nonspecific resistance to phytopathogens to combat resistant forms of hard-to-eradicate pathogens of plant diseases.

\section{References}

1. K. Xing, X. Zhu, X. Peng, S. Qin, Agron. Sustain. Dev., 35, 569 (2015)

2. A. Orynbayev, F. Dzhalilov, A. Ignatov. Archives of Phytopathology and Plant Protection, 53(7), 379 (2020)

3. B. Volksch, Microbial Ecology, 41(2), 132 (2001)

4. V. Fernández et al, Microorganisms, 8(9), 1431 (2020)

5. M. Elsharkawy, M. Shimizu, H. Takahashi, Plant Pathol J., 29, 193 (2013)

6. A. Obradovic, Plant Dis., 88(7), 736 (2004)

1. 7 E. I. Rabea, M. E.-T. Badawy, Biomacromolecules, 4, 1457 (2003)

7. S. Bautista-Banos, A.N. Hernandez-Lauzardo, et. al, Crop Protection, 25, 108 (2006)

8. J. Liu, J. Tian, X. Meng, Y. Xu, Post Biol Tech., 44, 300 (2007)

9. M. Rahman H, et al, Eur. J. Plant Pathol., 141(1), 147 (2015)

10. S. Marina, Molecules, 15, 7532 (2010)

11. C. Catalina, N. Rachel, K. Shaker, Plant Disease, 99, 676 (2015)

12. L. Orzali et al. Chitosan in Agriculture: A New Challenge for Managing Plant Disease (2017)

13. R. Cavalcanti, M.V. Resende, A.B. Zacaroni, Fitopatología Brasileira, 31(4), 372 (2006) 